\title{
Pembelajaran Matematika Anak Usia Dini Melalui Media Dadu dan Pengaruhnya ditinjau dari Perkembangan Kognitif
}

\author{
Qudsi Amin ${ }^{1)}$, Erna Wijayanti' ${ }^{2}$, Irmaidah ${ }^{3)}$ \\ ${ }^{1)}$ TK Terpadu Al-Mahrus Arjasa, ${ }^{2,3)}$ TK PGRI Seroja Jelbuk \\ Email: qaminra@gmail.com, erna71wijayanti@gmail.com, firmaidah@gmail.com
}

\begin{abstract}
Learning mathematics for early childhood requires ways and media that are suitable for children's development. Mathematics is a scientific discipline that covers almost all levels of education including early childhood education. The characteristic of early childhood learning is learning while playing as embodied in its curriculum at the level of the National Education System. Media dice games can be used in mathematics learning numerical recognition material that is directly related to aspects of children's cognitive development. This study examines the effect of dice media on cognitive development in the mathematics learning of early childhood education number recognition material. This type of research is quantitative causal with statistical tests used including normality test and homogeneity test and hypothesis testing using T test (T-test) or partial test using SPSS version 22 program. The conclusion of this study is that there are influences of media dice game on cognitive aspects learning material for number recognition in learning early childhood mathematics in the 2018/2019 academic year.
\end{abstract}

Keywords: AUD Mathematics Learning, Dice Media, Cognitive Development

\begin{abstract}
ABSTRAK
Pembelajaran matematika anak usia dini memerlukan cara dan media yang sesuai dengan perkembangan anak. Matematika merupakan disiplin keilmuan yang mencakup hampir seluruh tingkatan pendidikan termasuk pada pendidikan anak usia dini. Karakteristik pembelajaran anak usia dini adalah belajar sambil bermain sebagaimana termaktub dalam kurikulumnya pada tataran Sistem Pendidikan Nasional. Media permainan dadu dapat digunakan dalam pembelajaran matematika materi pengenalan angka yang berhubungan langsung dengan aspek perkembangan kognitif anak. Penelitian ini menelaah pengaruh media dadu terhadap perkembangan kognitif dalam pembelajaran matematika pendidikan anak usia dini materi pengenalan angka. Jenis penelitian ini adalah kuantitatif kausal dengan uji statistik yang digunakan meliputi uji normalitas dan uji homogenitas serta uji hipotesis mengunakan uji T (T-test) atau uji parsial menggunakan program SPSS versi 22. Kesimpulan dari penelitian ini adalah terdapat pengaruh media permainan dadu terhadap aspek kognitif materi pelajaran pengenalan angka dalam pembelajaran matematika anak usia dini semester ganjil tahun ajaran 2018/2019.
\end{abstract}


Kata Kunci :Pembelajaran Matematika AUD, Media Dadu, Perkembangan Kognitif

\section{PENDAHULUAN}

Pembelajaran dapat dipandang sebagai inti dari pendidikan, artinya capaian pendidikan sangat bergantung dengan pelaksanaan pembelajaran itu sendiri. Pentingnya pembelajaran telah disadari oleh pihak-pihak pelaksana maupun pemangku kebijakan pendidikan. Tingkat keberhasilan pembelajaran dipengaruhi oleh banyak faktor dan aspek baik secara langsung maupun tidak langsung. Desain pembelajaran yang baik akan menciptakan suasana belajar yang kondusif dan pada akhirnya dapat meningkatkan capaian belajar. Tentu peran guru dalam pembalajaran sangatlah dominan dan menjadi penentu kesuksesan hal tersebut.

Adanya karakteristik materi pelajaran atau mata pelajaran sekalipun tidak dapat dipungkiri. Keniscayaan bahwa tiap bidang studi, kajian dan disiplin keilmuan tertentu mempunyai ciri khas dan sudut pandang masing-masing. Mata pelajaran matematika merupakan bidang keilmuan yang menjadi dasar dari keilmuan lainnya. Karena perannya yang sangat diperlukan oleh bidang keilmuan lain maka urgensi matematika teramat tinggi sehingga kesadaran untuk memahami konsep-konsep dasar matematika telah menjadi hal utama bagi tiap orang. Meskipun demikian pentingnya namun masih saja ada anggapan bahwa matematika merupakan pelajaran yang sulit, membosankan, menakutkan dan kurang berguna dalam kehidupan seharihari (Asikin, 2012). Asumsi ini dapat dimaklumi bagi seorang yang kesulitan dalam memahami matematika, tidak mengerti fungsi matematika dalam kehidupan dan kurangnya kesadaran akan matematika sebagai pondasi berpikir. Dalam kehidupan sehari-hari seorang tidak dapat terlepas dari penggunaan konsep-konsep matematika meskipun hanya dalam hal yang sederhana. Oleh karenanya maka pembelajaran matematika perlu mendapatkan perhatian khusus utamanya pada tingkat pendidikan anak usia dini.

Pendidikan anak usia dini merupakan pendidikan awal yang didalamnya meliputi pendidikan non formal dan formal. Pendidikan anak usia dini merupakan layanan pendidikan yang memberikan bentuk pembelajaran sambil bermain sesuai dengan tingkat perkembangan anak. Dinyatakan bahwa pendidikan anak usia dini 
adalah upaya pemberian rangsangan pendidikan bagi anak usia dini usia $0-6$ tahun yang dilakukan melalui pemberian rangsangan pendidikan untuk membantu pertumbuhan dan perkembangan jasmani dan rohani agar anakmemiliki kesiapan dalam memasuki pendidikan yang lebih lanjut (UUD No.20 Tahun 2003 tentang Pendidikan Nasional pasal 1 ayat 14). Berdasarkan pernyataan tersebut maka pendidikan anak usia dini bersifat stimulus awal agar anak memperoleh kesiapan untuk pendidikan selanjutnya yakni sekolah dasar. Usia yang menjadi ranah pendidikan anak usia dini adalah dari 0 hingga 6 tahun dan mencakup aspek pertumbuhan dan perkembangan jasmani dan rohani anak.

Pencapaian pertumbuhan jasmani dan perkembangan rohani pada pendidikan anak usia dini diinterpretasikan pada aspek kognitif, moral nilai agama, bahasa, fisik motorik, seni dan sosial emosional. Salah satu aspek perkembangan yang bertalian erat dengan kemampuan mengenal angka atau menghitung sederhana adalah aspek kognitif. Menghitung merupakan cara belajar mengenal nama angka, kemudian menggunakan nama angka tersebut untuk mengidentifikasi jumlah benda (Sujiono, dkk, 2008). Banyak upaya dalam mengembangkan aspek kognitif materi mengenal angka misalnya dengan menggunakan media pembelajaran. Media Pembelajaran pada proses belajar mengajar cenderung diartikan, sebagai alat-alat grafis, photografis, atau elektronis untuk menangkap, memproses, dan menyusun kembali informasi visual atau verbal (Arsyad, 2007). Penggunaan media pembelajaran sangat membantu guru dalam menyampaikan pesan materi pelajaran dan memberikan rangsangan tersendiri bagi anak sehingga perhatian mereka akan terpusat pada penyampaian materi oleh guru. Namun demikian penggunaan media pembelajaran harus relevan dengan materi pelajaran yang akan disampaikan.

Dadu merupakan media permainan yang dapat digunakan sebagai media pembelajaran khususnya materi pengenalan angka atau menghitung sederhana. Dadu yang merupakan alat permaianan dengan bentuk kubus mempunyai enam sisi yang berisikan titik mulai dari satu hingga enam titik. Modifikasi dari sisi dadu menjadi angka-angka yang dikehendaki untuk penyampaian materi pengenalan angka akan sangat membantu dalam keberhasilan perkembangan kognitif tersebut. Potensi permainan dadu untuk dimanfaatkan pada penyampaian materi tersebut masih jarang dilakukan. Oleh karenanya maka penelitian ini bermaksud menerapkan permainan 
edukatif berupa permainan dadu dalam pembelajaran matematika anak usia dini pada materi pengenalan angka dengan meninjau pengaruhnya pada aspek perkembangan kognitif anak.

Implementasi penggunaan media permainan dadu dalam pembalajaran matematika anak usia dini dilaksanakan pada TK Terpadu Al-Mahrus Arjasa dan TK PGRI Seroja Jelbuk kabupaten Jember semester ganjil tahun pelajaran 2018/2019. Hal ini karena pada kedua lembaga tersebut belum pernah menerapkan media permainan dadu dalam pembelajaran matematika anak usia dini materi pengenalan angka. Selain menerapkan media pembelajaran berupa dadu permainan tersebut, peneliti juga menganalisis pengaruhnya terhadap aspek perkembangan kognitif sehingga judul penelitian ini adalah "Pembelajaran Matematika Anak Usia Dini Melalui Media Dadu dan Pengaruhnya ditinjau dari Perkembangan Kognitif’.

\section{METODE PENELITIAN}

Penelitian ini termasuk pada rumpun penelitian kuantitatif jenis kausal, yakni penelitian yang menelaah pengaruh variabel tertentu (variabel bebas) pada variabel tertentu lainnya (variabel terikat) dengan menggunakan metode statistik sehingga hasil simpulannya mengacu pada angka-angka (Sugiono, 2008). Penelitian ini mempunyai tahapan 1) observasi awal, 2) penyusunan rancangan dan instrumen penelitian, 3) perlakuan dan pengambilan data lapangan dan 4) penyusunan laporan dan publikasi hasil penelitian (Suharsimi, 2002). Tahapan penelitian ini merupakan tahapan penelitian kuantitatif kausalitas sederhana dengan variabel bebas dan terikat tunggal.

Adapun instrumen penelitian yang digunakan adalah 1) lembar observasi awal, 2) rubrik wawancara, 3) lembar pengamatan siswa dan 4) angket. Sedangkan responden penelitian adalah anak usia dini TK Terpadu Al-Mahrus Arjasa sebanyak 30 anak dan TK PGRI Seroja Jelbuk sebanyak 32 anak semester ganjil tahun pelajaran 2018/2019. Penentuan tempat penelitian adalah mengunakan purposive sampling area yakni pemilihan lokasi berdasarkan asumsi-asumsi tertentu oleh peneliti. Uji Statistik yang digunakan dalam penelitian ini adalah uji data hasil penelitian dengan uji normalitas dan uji homogenitas dan uji hipotesis mengunakan uji T (T-test) atau ujia parsial menggunakan program SPSS versi 22. 


\section{HASIL DAN PEMBAHASAN}

1. Hasil Observasi Awal

Obervasi awal yang dilakukan peneliti sebelum melakukan perlakukan dan pengambilan data lapangan menunjukkan bahwa kondisi TK Terpadu Al-Mahrus Arjasa dan TK PGRI Seroja Jelbuk kabupaten Jember adalah baik, strategis dan memenuhi standar. Kondisi baik adalah pada keadaan gedung sekolah dan lingkungan sekitar yang sangat mendukung terhadap proses pembelajaran dan jauh dari kebisingan. Sedangkan strategis bermakna bahwa lokasi sekolah sangat mendukung dalam hal akses jalan dan tidak jauh dari pusat kota. Aspek memenuhi standar adalah bahwa pada sekolah tersebut tersedia alat permainan edukatif penunjang pembelajaran pendidikan anak usia dini kecuali media permainan dadu. Selain alat permainan edukatif, sarana pembelajaran lain jug tersedia dengan baik dan memenuhi standar minimal.

2. Hasil Penyusunan Rancangan dan Instrumen Penelitian

Penyusunan rancangan penelitian dilakukan dalam bentuk proposal penelitian yang mencakup segala hal terkait tahapan dan langkah-langkah penelitian. Langkah penelitian meliputi pengumpulan data awal, penerapan media permainan dadu dalam pembelajaran matematika materi pengenalan angka, pengambilan data hasil perlakukan berupa hasil pengamatan dan angket serta tahapan berikutnya adalah pengolahan data secara statistik sehingga dihasilkan simpulan hasil uji serta penyusunan laporan. Adapun tahapan penelitian dapat dilihat pada bagan berikut ini: 
Rangkaian Kegiatan

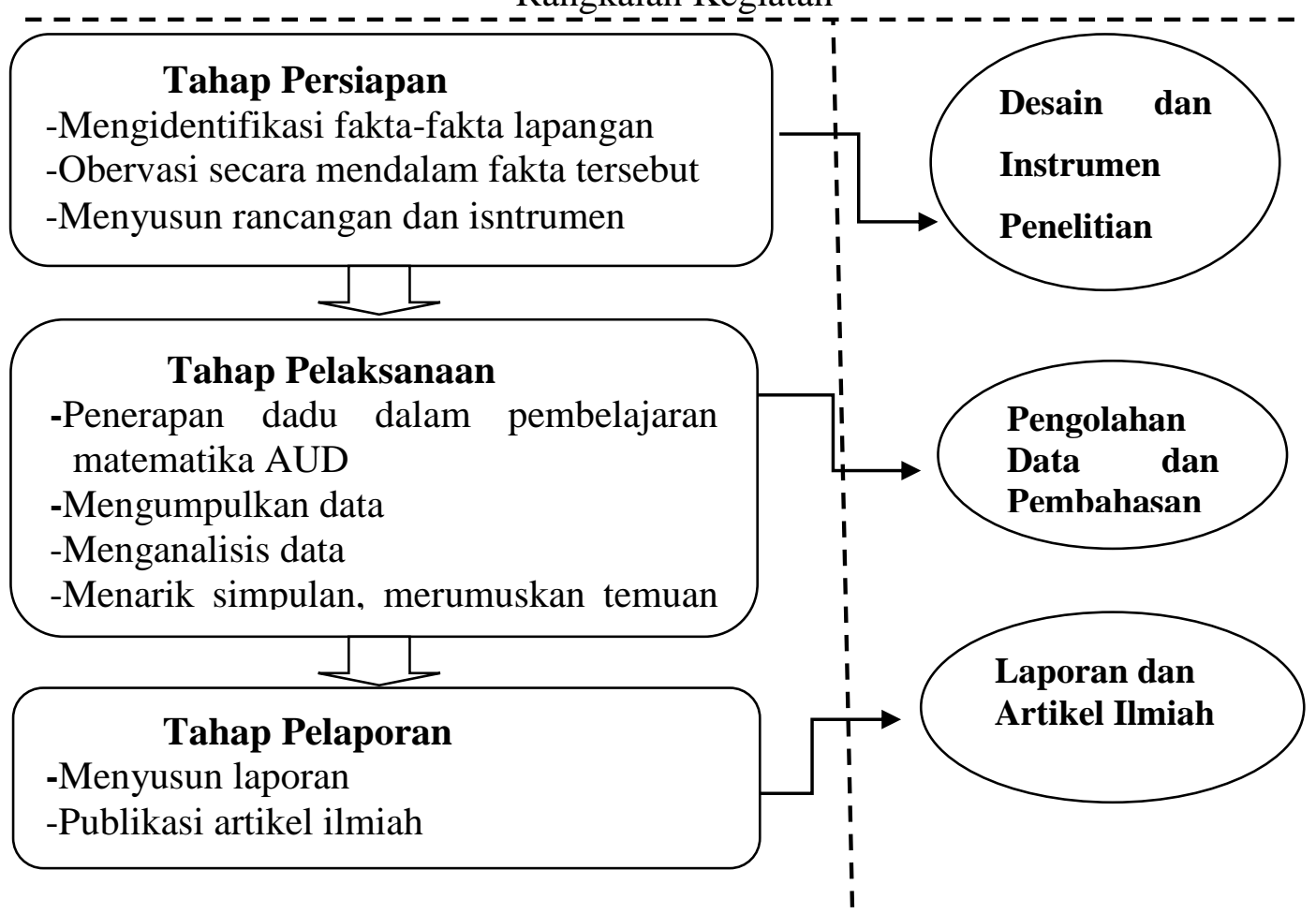

Gambar 1. Langkah-Langkah Penelitian

Instrumen penelitian disusun secara mendalam dan kemudian dikonsultasikan pada 2 orang ahli. Rekomendasi oleh dua orang ahli dijadikan pertimbangan dan revisi instrumen. Hasil revisi berdasarkan saran dua orang ahli ini kemudian digunakan pada pengambilan data lapangan, instrumen yang dimaksudkan adalah angket dan lembar pengamatan.

3. Hasil Perlakukan dan Pengambilan Data Lapangan

Penerapan permainan dadu dalam pembelajaran matematika materi pengenalan angka pada anak usia dini TK Terpadu Al-Mahrus Arjasa dan TK PGRI Seroja Jelbuk kabupaten Jember semester ganjiltahunpelajaran 2018/2019 berjalan sesuai rancangan penelitian. Pembelajaran matematika anak usia dini materi pengenalan angka dilaksanakan dengan menggunakan media permainan dadu.

Hasil pengamatan peneliti pada saat pembelajaran berlangsung menunjukkan bahwa anak usia dini lebih tertarik dan fokus terhadap penyampaian materi pelajaran oleh guru. Sikap yang diperlihatkan oleh anak sangat kooperatif dan antusias mengikuti proses pembelajaran. Nampak sekali ekspresi senang dan dapat menangkap materi pelajaaran meskipun dianggap sebagai bidang studi yang rumit 
dan sulit. Agar memperoleh hasil dari perlakuan yang tepat dan terukur, maka peneliti melakukan isian angket yang dibantu oleh guru dan orangtua anak yang hadir.

Angket tersebut berisikan pertanyaan-pertanyaan mengenai perkembangan kognitif anak mengacu pada materi pelajaranyang telah disampaikan. Angket menggunakan pedoman penskoran atau kisi-kisi sebagai berikut:

Tabel 1. Pedoman Penskoran Angket Pengenalan Angka

\begin{tabular}{|c|c|c|c|}
\hline \multirow{2}{*}{ No } & \multirow{2}{*}{ Indikator } & \multicolumn{2}{|c|}{ Penilaian } \\
\hline & & $\mathrm{Ya}$ & Tidak \\
\hline 1 & $\begin{array}{l}\text { Anak mampu mengenal angka } 1 \text { dengan } \\
\text { menunjukkan titik yang sesuai pada sisi dadu } \\
\text { dengan tepat }\end{array}$ & & \\
\hline 2 & $\begin{array}{l}\text { Anak mampu mengenal angka } 2 \text { dengan } \\
\text { menunjukkan titik yang sesuai pada sisi dadu } \\
\text { dengan tepat }\end{array}$ & & \\
\hline 3 & $\begin{array}{l}\text { Anak mampu mengenal angka } 3 \text { dengan } \\
\text { menunjukkan titik yang sesuai pada sisi dadu } \\
\text { dengan tepat }\end{array}$ & & \\
\hline 4 & $\begin{array}{l}\text { Anak mampu mengenal angka } 4 \text { dengan } \\
\text { menunjukkan titik yang sesuai pada sisi dadu } \\
\text { dengan tepat }\end{array}$ & & \\
\hline 5 & $\begin{array}{l}\text { Anak mampu mengenal angka } 5 \text { dengan } \\
\text { menunjukkan titik yang sesuai pada sisi dadu } \\
\text { dengan tepat }\end{array}$ & & \\
\hline 6 & $\begin{array}{l}\text { Anak mampu mengenal angka } 6 \text { dengan } \\
\text { menunjukkan titik yang sesuai pada sisi dadu } \\
\text { dengan tepat }\end{array}$ & & \\
\hline 7 & $\begin{array}{l}\text { Anak mampu menyebutkan angka yang ditunjukkan } \\
\text { oleh mata/sisi dadu dengan menggunakan lemparan } \\
1 \mathrm{kali}\end{array}$ & & \\
\hline 8 & $\begin{array}{l}\text { Anak mampu menyebutkan angka yang ditunjukkan } \\
\text { oleh mata/sisi dadu dengan menjumlahkan } \\
\text { lemparan pertama dan kedua }\end{array}$ & & \\
\hline 9 & $\begin{array}{l}\text { Anak mampu menyebutkan angka yang ditunjukkan } \\
\text { oleh mata/sisi dadu dengan menjumlahkan } \\
\text { lemparan kedua dan ketiga }\end{array}$ & & \\
\hline 10 & $\begin{array}{l}\text { Anak mampu menyebutkan angka yang ditunjukkan } \\
\text { oleh mata/sisi dadu dengan menjumlahkan } \\
\text { lemparan ketiga dan keempat }\end{array}$ & & \\
\hline & Skor yang dicapai & & \\
\hline & Skor maksimum & & \\
\hline
\end{tabular}

Keterangan: Ya: 1 Tidak : 0 
Berdasarkan pengisian angket yang telah dilakukan, maka diperoleh data akumulasi sebagai berikut:

Tabel 2. Akumulasi Data Aspek Kognitif Pengenalan Angka

\begin{tabular}{|c|c|c|c|c|}
\hline \multirow{2}{*}{ SKOR } & \multicolumn{2}{|c|}{ TK Terpadu Al-Mahrus } & \multicolumn{2}{c|}{ TK PGRI Seroja } \\
\cline { 2 - 5 } & Jumlah & Prosentase & Jumlah & Prosentase \\
\hline $0-2$ & 0 & 0 & 0 & 0 \\
\hline $3-4$ & 3 & 10 & 0 & 0 \\
\hline $5-6$ & 3 & 10 & 8 & 25 \\
\hline $7-8$ & 6 & 20 & 16 & 50 \\
\hline $9-10$ & 18 & 60 & 8 & 25 \\
\hline
\end{tabular}

Berdasarkan Tabel 2 diatas, maka dapat dijelaskan bahwa perolehan skor aspek kognitif pengenalan angka pada TK Terpadu Al-Mahrus terlihat anak yang memperoleh skor 3-4 sebanyak 3 orang (10\%), 5-6 sebanyak 3 orang (10\%), 7-8 sebanyak 6 orang (20\%) dan 9-10 sebanyak 18 orang (60\%). Sedangkan data pada TK PGRI Seroja anak yang memperoleh skor 3-4 sebanyak 0 orang (0\%), 5-6 sebanyak 8 orang (25\%), 7-8 sebanyak 16 orang (50\%) dan 9-10 sebanyak 8 orang (25\%). Skor terendah yakni 0-2 tidak didapatkan pada kedua data diatas artinya bahwa skor 0-2 tidak diperoleh anak baik pada TK Terpadu Al-Mahrus maupun TK PGRI Seroja.

\section{Hasil Uji dan Keputusan Statistik}

Berdasarkan data hasil penelitian maka akan diolah dengan beberapa uji sebagai berikut:

a) Uji Normalitas data

Ujinormalitas ini digunakan untuk menyelidiki apakah data dalam penelitian ini berdistribusi normal atau tidak. Pada penelitian yang akan dilakukan untuk uji normalitasnya akan digunakan program SPSS versi 22.0 dengan Kriteria Kolmogorov-Smirnov, dan Shapiro wilkdenganprosedur (Suharsimi, 2002): 1). Menetapkan Hipotesis Ho: sampel berasal dari populasi berdistribusi tidak normal, Ha: sampel berasal dari populasi berdistribusi normal. 2). Menetapkan taraf signifikansi $(\alpha)$ Taraf signifikansi adalah angka yang menunjukkan seberapa besar peluang terjadinya kesalahan analisa. Taraf signifikansi yang akan digunakan dalam penelitian yang akan dilakukan adalah 0,05 atau 5\%.3). Keputusan uji, Ho ditolak jika p-value $<\alpha$. 
Mengacu pada ketentuan uji normalitas tersebut diperoleh hasil uji sebagai berikut:

Tabel 3. Ringkasan Hasil Uji Normalitas

\begin{tabular}{|c|c|c|}
\hline Uji Normalitas & Sig. Kognitif Pengenalan Angka & Keterangan \\
\hline $\begin{array}{l}\text { TK Terpadu Al-Mahrus } \\
\text { Arjasa }\end{array}$ & $0,065>0,05$ & Normal \\
\hline PGRI Seroja & $0,056>0,05$ & Normal \\
\hline
\end{tabular}

Berdasarkan hasil uji normalitas sebagaimana ditunjukkan pada Tabel 3 di atas, maka dapat dinyatakan bahwa data pada TK Terpadu Al-Mahrus Arjasa dan TK PGRI Seroja berdistribusi normal.

b) Uji Homogenitas

Tujuan dari uji homogenitas adalah untuk mengetahui apakah sampel berasal dari populasi yang berdistribusi dari variasi homogen atau tidak (Sugiono, 2016). Jika signifikansi > 0,05 maka data berdistribusi homogen sehingga Ho ditolak yang artinyasampelberasaldaripopulasi yang tidakhomogen. Pengujian homogenitas disini menggunakan SPSS versi 22. Hasil perhitungannnya disajikan sebagai berikut:

Tabel 4.Uji Homogenitas dengan Levene's Test

\begin{tabular}{|c|c|c|}
\hline UjiHomogen & Signifikansi & Keterangan \\
\hline $\begin{array}{l}\text { TK Terpadu Al-Mahrus } \\
\text { Arjasa }\end{array}$ & $0,06>0,05$ & Homogen \\
\hline PGRI Seroja & $0,07>0,05$ & Homogen \\
\hline
\end{tabular}

Berdasarkan uji Lavene's test diatas, maka diperoleh hasil uji homogen dengan data TK Terpadu Al-Mahrus Arjasa homogen dan data PGRI Seroja homogen.Dengan ini berarti pengujian selanjutnya yakni uji hipotesis menggunakan uji T atau uji beda dapat dilakukan.

c) Uji Hipotesis

Uji hipotesis pada penelitian ini menggunakan uji $\mathrm{T}$ atau uji parsial yang akan melihat pengaruh penggunaan media dadu sebagai variabel bebas terhadap aspek kognitif pengenalan angka sebagai variabel terikat. Uji parsial digunakan untuk mengetahui pengaruh variabel independen terhadap variabel dependen secara parsial (Sugiono, 2013). Jika $t_{\text {hitung }} \geq t_{\text {tabel }}$ pada taraf signifikansi 0,05 maka terdapat 
pengaruh yang signifikan antara variabel bebas terhadap variabel terikat. Namun jika jika $t_{\text {hitung }}<\mathrm{t}_{\text {tabel }}$ maka tidak terdapat pengaruh yang signifikan antara varibel bebas terhadap variabel terikat. Berikut ini disajikan hasil perhitungan program SPSS versi 22 terkait dengan uji tersebut:

Tabel 5. Hasil Uji Parsial Variabel

\begin{tabular}{|c|c|c|c|c|c|c|c|c|c|c|c|c|}
\hline \multirow{3}{*}{ Variabel } & \multicolumn{12}{|c|}{ Coefficients $^{\mathrm{a}}$} \\
\hline & \multicolumn{2}{|c|}{$\begin{array}{c}\text { Unstandardized } \\
\text { Coefficients }\end{array}$} & $\begin{array}{c}\text { Standardi } \\
\text { zed } \\
\text { Coefficie } \\
\text { nts }\end{array}$ & \multirow{2}{*}{$\mathrm{t}$} & \multirow{2}{*}{ Sig. } & \multicolumn{2}{|c|}{$\begin{array}{c}95.0 \% \\
\text { Confidence } \\
\text { Interval for B }\end{array}$} & \multicolumn{3}{|c|}{ Correlations } & \multicolumn{2}{|c|}{$\begin{array}{c}\text { Collinearity } \\
\text { Statistics }\end{array}$} \\
\hline & B & $\begin{array}{l}\text { Std. } \\
\text { Error }\end{array}$ & Beta & & & $\begin{array}{l}\text { Lower } \\
\text { Bound }\end{array}$ & $\begin{array}{l}\text { Upper } \\
\text { Bound }\end{array}$ & Zero-order & Partial & Part & $\begin{array}{c}\text { Tolera } \\
\text { nce }\end{array}$ & VIF \\
\hline (Constant) & 1.121 & 1.340 & & -.837 & 409 & 3.845 & 1.602 & & & & & \\
\hline Dadu & 254 & .060 & .273 & 4.229 & 000 & 132 & .376 & 151 & .587 & 271 & 983 & 1.018 \\
\hline Kognitif & 806 & .056 & .923 & 14.273 & 000 & 691 & .920 & 887 & .926 & 915 & 983 & 1.018 \\
\hline
\end{tabular}

Pada Table 5 menunjukkan hasil perhitungan uji parsial variabel pengaruh media permainan dadu terhadap aspek kognitif pengenalan angka dalam pembelajaran matematika anak usia dini TK Terpadu Al-Mahrus dengan thitung $(4,229) \geq \mathrm{t}_{\text {-tabel }}(1,688)$ maka $\mathrm{H}_{0}$ ditolak, dan $\mathrm{H}_{\mathrm{a}}$ diterima: "Terdapat Pengaruh Media Permainan Dadu terhadap Aspek Kognitif Materi Pelajaran Pengenalan Angka dalam Pembelajaran MatematikaAnak Usia Dini TK Terpadu Al-Mahrus Arjasa Semester Ganjil Tahun Ajaran 2018/2019”. Sedangkan hasil uji parsial pengaruh media permainan dadu terhadap aspek kognitif pengenalan angka dalam pembelajaran matematika anak usia dini TK PGRI Seroja dengan"t-hitung $(14,273) \geq \mathbf{t}$ tabel $(1,688)$ maka $\mathrm{H}_{0}$ ditolak, dan $\mathrm{H}_{\mathrm{a}}$ diterima: "Terdapat Pengaruh Media Permainan Dadu terhadap Aspek Kognitif Materi Pelajaran Pengenalan Angka dalam Pembelajaran MatematikaAnak Usia Dini TK PGRI Seroja Jelbuk Semester Ganjil Tahun Ajaran 2018/2019”.

Berdasarkan hasil uji parsial variabel tersebut di atas, maka dapat dinyatakan bahwa "Terdapat Pengaruh Media Permainan Dadu terhadap Aspek Kognitif Materi Pelajaran Pengenalan Angka dalam Pembelajaran Matematika Anak 
Usia Dini TK Terpadu Al-Mahrus Arjasadan TK PGRI Seroja Jelbuk Semester Ganjil Tahun Ajaran 2018/2019”. Artinya penerapan media permainan dadu berpengaruh pada aspek kognitif secara keseluruhan baik pada TK Terpadu AlMahrus Arjasa maupun TK PGRI Seroja Jelbuk.

Hasil penelitian ini dapat dijelaskan dengan membahas secara mendalam dari unsur dan aspek yang mendukung mulai dari pembelajaran, dadu sebagai media permainan sekaligus media pembelajaran serta materi pengenalan angka keterkaitannya dengan aspek perkembangan kognitif. Pembelajaran memiliki fungsi, diantaranya: (a) Untuk mengembangkan seluruh kemampuan yang dimiliki anak sesuai dengan tahap perkembangannya, (b) Mengenalkan anak dengan dunia sekitar, (c) Mengembangkan sosialisasi anak, (d) Mengenalkan peraturan dan menanamkan disiplin pada anak, (e) Memberikan kesempatan kepada anak untuk menikmati masa bermainnya (Sujiono, 2008). Dari beberapa fungsi pembelajaran tersebut mulai dari pengambangan seluruh aspek pada anak, mengajarkan disiplin, sosialisasi dan yang paling relevan bagi anak usia dini adalah fungsi kesempatan bermain sesuai tahap perkembangnnya.

Anak usia dini tidak dapat dilepaskan dari aktivitas bermain karena memang sesuai dengan tahap perkembangannya. Selain sebagai bagian dari perkembangannya, ternyata bermain bagi anak dapat menumbuhkan rasa senang dalam mengikuti pembelajaran (Fadillah, 2014). Oleh karenanya penerapan dadu yang merupakan media permainan sangat cocok dan sesuai dengan karakteristik anak usia dini. Dadu yang digunakan dalam pembelajaran matematika materi pengenalan angka secara tidak langsung akan menjadi media pembelajaran karena menjadi perantara penyampaian materi pelajaran selain memang sebagai media permainan.

Banyak manfaat dan guna media pembelajaran jika diterapkan dalam roses pembelajaran sehingga jenis dan varian media pembelajaran tidak terhitung jumlahnya. Jenis dan varian media pembelajaran pada dasarnya dikembangkan sesuai dengan fungsinya. Fungsi media pembelajaran diantaranya adalah1) Fungsi atensi2) Fungsi afektif3) Fungsi kognitif4) Fungsi kompensatoris(Arsyad, 2007). Atensi merupakan fungsi media pembelajaran yang dapat menarik perhatian anak sehingga fokus terhadap materi pelajaran yang disampaikan guru. Afektif menunjukkan fungsi dapat menimbulkan sikap dan rasa anak terhadap proses 
pembelajaran. Kognitif adalah fungsi media pembelajaran yang dapat membantu meningkatkan daya tangkap dan ingat anak terhadap informasi/materi pelajaran. Sedangkan kompensatoris adalah fungsi media yang dapat menggantikan peran tulisan menjadi bentuk visual atau lainnya sehingga dapat membantu anak yang sulit memahami materi melalui tulisan.

Aspek perkembangan kognitif erat kaitannya dengan kemampuan berpikir atau tingkat kognisi anak. Kognisimeliputi proses dimanapengetahuandiperoleh, disimpandandimanfaatkan (Sujiono, 2008). Merujuk pada pendapat tersebut, maka perkembangan kognitif adalah bertalian dengan perolehan, penyimpanan dan pemanfaatan informasi termasuk pada materi pengenalan angka. Lebih tegas dinyatakan bahwa tingkat pencapaian perkembangan kognitif anak usia 5-6 tahun, yaitu: (1) Menyebutkan lambang bilangan 1-10, (2) Mencocokkan bilangan dengan lambangbilangan, (3) Mengenal berbagai macam lambang huruf vokal dan konsonan (Peraturan Menteri Pendidikan dan Kebudayaan Republik Indonesia Nomor 137 Tahun 2014). Oleh karenanya penerapan dadu sebagai media permainan sekaligus berfungsi sebagai media pembelajaran sangat sesuai dengan tahap perkembangan anak usia dini sehingga berpengaruh pada aspek perkembangan kognitifnya utamanya dalam pembelajaran matematika materi pengenalan angka.

\section{KESIMPULAN DAN SARAN}

Kesimpulan dari hasil penelitian ini adalah terdapat pengaruh media permainan dadu terhadap aspek kognitif materi pelajaran pengenalan angka dalam pembelajaran matematika anak usia dini TK Terpadu Al-Mahrus Arjasadan TK PGRI Seroja Jelbuk Semester Ganjil Tahun Ajaran 2018/2019. Artinya bahwa penggunaan media dadu dalam pembelajaran matematika anak usia dini materi pengenalan angka sangat cocok dan tepat karena relevan dengan materi dan tahap perkembangan anak. Selain itu jug sesuai dengan karakteristik pembelajaran anak usia dini yaitu belajar sambil bermain.

Saran dari penelitian ini adalah 1) Pendidik khususnya pada tataran pendidikan anak usia dini hendaknya menggunakan media dadu atau yang sejenisnya dalam penyampaian materi pengenalan angka sehingga materi tersebut dapat dipahami dengan mudah. 2) Hasil penelitian ini hendaknya dapat dijadikan acuan 
dalam pengembangan penelitian selanjutnya sehingga akan semakin sempurna dan dapat dapat memperkaya wawasan keilmuan.

\section{REFERENSI}

Arikunto, Suharsimi. 2016. Prosedur Penelitian. Jakarta: Renika Cipta

Asikin, M. 2012. Basics of Mathematics Learning Process 1. Semarang: FMIPA Unnes

Azhar, Arsyad. 2007. Media Pengajaran. Jakarta: Raja Grafindo

Depdiknas. 2010. Kurikulum Pedoman Pengembangan Program Pembelajaran di Taman Kanak-kanak. Jakarta: Depdiknas.

Fadillah, dkk. 2014. Edutainment Pendidikan Anak Usia Dini. Jakarta: Kencana.

Peraturan Menteri Pendidikan dan Kebudayaan Republik Indonesia Nomor 137 Tahun 2014 tentang Standar Nasional Pendidikan Anak Usia Dini.

Sugiono. 2008. Metode Penelitian Pendidikan Pendekatan Kuantitatif, Kualitatif, dan $R \& D$. Bandung: Alfabeta.

Sujiono, Yuliani Nuraini dkk. 2008. Metode Pengembangan Kognitif. Jakarta: Universitas terbuka. 